\title{
HEALTH CONTROL OF PIG HERDS ON COMMERCIAL FARMS
}

Jovan Bojkovski1 ${ }^{1 \star}$, Teodora Vasiljević2 , Dragica

Stojanović ${ }^{3}$, Dragan Rogožarski ${ }^{4}$

${ }^{1}$ Faculty of Veterinary Medicine, Universty of Belgrade, Belgrade, Sebia

${ }^{2}$ Patent co., Belgrade, Serbia

${ }^{3}$ Faculty of Agriculture, Department of Veterinary Medicine, University of Novi Sad, Novi Sad, Serbia

${ }^{4}$ Veterinary Specialistic Institute, Požarevac, Serbia

\section{Abstract}

The concept of modern industrial production of pigs on commercial farms is based, among other things, on the implementation of biosecurity measures as well as solving problems of environmental protection, which greatly burden the production. It is well known that good health is a prerequisite for good pig reproduction, that is, a successful and profitable production. The health status of the herd depends on many factors such as the maintenance technology, nursing, nutrition, organization, level of staff training and systematic implementation of good health care policies. Today, we are witnessing high incidence of bacterial diseases, viral etiology and certain parasites that seriously affect the pig production in intensive farming conditions. Keeping such diseases under control is possible only by applying appropriate prophylactic and therapeutic measures, as well as by increased monitoring by professional services.

Keywords: swine, breeding diseases, reproduction, biosecurity,

\footnotetext{
1* e-mail: bojkovski@vet.bg.ac.rs
} 


\title{
KONTROLA ZDRAVLJA STADA SVINJA NA KOMERCIJALNIM FARMAMA
}

\author{
Jovan Bojkovski ${ }^{1}$ Teodora Vasiljević 2 , Dragica \\ Stojanović 3 , Dragan Rogožarski ${ }^{4}$ \\ ${ }^{1}$ Fakultet veterinarske medicine, Univerzitet u Beogradu, Beograd \\ ${ }^{2}$ Patent co, Beograd \\ ${ }^{3}$ Poljoprivredni fakultet, Departman Veterinarske \\ Medicine, Univerzitet u Novom Sadu, Novi Sad \\ ${ }^{4}$ Veterinarski specijalistički institut Požarevac
}

\section{Kratak sadržaj}

Koncept savremene industrijske proizvodnje svinja na komercijalnim farmama zasnovan je, između ostalog i na sprovođenju biosigurnosnih mera, kao i na rešavanju problema ekološke zaštite koji u velikoj meri opterećuju proizvodnju. Poznato je da dobro zdravlje svinja predstavlja preduslov dobre reprodukcije, odnosno uspešne i profitabilne proizvodnje u svinjarstvu. Zdravstveni status stada zavisi od velikog broja činilaca, kao što su su tehnologija držanja, nege, ishrane, organizacija, stepen obučenosti kadrova kao i sistematsko sprovođenje mera zdravstvene zaštite . Danas smo svedoci da veliki broj oboljenja bakterijske, virusne etiologije kao i pojedine parazitoze mogu ozbiljno ugroziti proizvodnju svinja u intenzivnom uzgoju. Ove bolesti moguće je primenom profilaktičkih i terapeutskih mera, kao i pojačanim nadzorom stručnih službi držati pod kontrolom.

Ključne reči: svinje, uzgojne bolesti, repordukcija biosigurnost

\section{INTRODUCTION}

In intensive pig farming, is more valid parameters that can be used to show the success and profitability of production, such as the number of live or weaned piglets, length of fattening period, the number of non-reproductive days annual etc. Today it is common pig production on commercial farms would present a number of breeding piglets and fattening pigs per sow delivered during calendar year. The production parameters vary considerably between countries with more or less developed production pigs (Radojičić at al. 2002). To be able to work on improving the production of pigs on the farm it is important to assure good health of breeding sows and piglets in the first days after farrowing ( Bojkovski et.al. 2005, 2011, 2013b). 
In this review paper presents a summary of our research that are related to solving reproductive health and biosecurity issues on commercial swine farms as well as an overview of environmental contaminants that were present on farms with some of the possible solutions.

Flexible cooperation of farm breeding with professional services, with respect to the implementation of technical knowledge and application of range of biotechnical measures and putting the emphasis on prevention of disease in order to promote the good health of pigs. It is possible to improve the welfare of pigs an actual production (Hristov et. al. 2008)

\section{COMMON HEALTH - REPRODUCTIVE PROBLEMS ON COM- MERCIAL PIG FARMS}

In intensive pig production, the control of the reproduction herd is the primary task. It is well known that in comparison to other breed of domestic animals, swine are characterized by a very high reproductive potential, given that the early sexually mature, have a high value of ovulation, the period of gestation and the lactation period is relatively short and can quickly establish a pregnancy after weaning the previous litter. From an economic point of view, proper, regular reproductive activity of pigs is of great importanceThe reproductive efficiency of a herd is usually estimated on the basis of: age of female animals at first farrowing, the length of their reproductive exploitation, the duration of the interval between individual farrowing, and the size of the litter at weaning. Reproductive activity of pigs is influenced by the number of factors including hereditary, endogenous (hormones, immunoglobulins, enzymes) a $\mathrm{dn}$ environmental ones, the presence of pathogens as well as management and production technology ( Uzelac, Vasiljević , 2011. ). Reproductive efficiency is further determined by the system of keeping, diet, season , farm location, microclimate, implementation of biosecurity measures, herd size, herd health status (presence of breeding, parasitic and infectious diseases ), body score condition, and methods of artificial insemination (Lončarević et al ., 1997 Petrujkić et al . 2011).

Infertility is a common problem on commercial farms. The causes of infertility are diverse and numerous. Current problem at most of our farms is the emergence of seasonal infertility that is present during summer months and is a serious impediment to producers who want to maximize reproductive efficiency of the herd ( Petrujkić et al., 2009, 2010 , 2011). In this sense, in intensive pig production today much attention is paid to optimizing the microclimate conditions in housing facilities by using computerized ventilation systems and 
automated equipment for air conditioning, lighting, feeding, manure disposal , etc. Programming of desired parameters provides favorable conditions for the animals and maximize expressing of their genetic potential and increase their reproductive productivity while greatly reducing the stress.

Adequate health care for farm animals, high level of hygiene of animals, vehicles and staff, as well as the strict application of all desired methods in the technology of artificial insemination are the primary requirements to accomplish high reproductive efficiency of breeding animals (Stančić et al .2012).

Conventional assessment of semen quality in boars as an important segment in the technology of artificial insemination is widely practiced on our commercial farms. Classical procedure for evaluation of semen quality in condition of commercial breeding can identify the ejaculates with low fertilization potential; however, it did not prove effective in predicting fertility parameters in the field conditions (Tsakmakidis , 2011). Therefore, in order to overcome the problem of infertility and to control the reproductive efficiency of pigs, a cooperation with the veterinary institute offers a range of novel laboratory methods such as motion estimation using computer analyzer (CASA ), automated sperm morphology analysis ( ASMA ), flow cytometry for determination of chromatin integrity, HOS test etc. Thus, the fertility of boars can be continuously monitored enabling a prompt response to the immediate production. Technology of the preparation of heterosperm insemination doses involving sperm of two or more terminal boars has been applied in the process of artificial insemination at our commercial farms to produce a large number of piglets per sow ( Vasiljević , 2012)

Use of deep- frozen semen is common on industrial swine farms. The advantage of frozen semen is its ability to preserve the genetic material for a longer period, and significantly reduce the risk of introduction of the disease in the herd (Stanković et al ., 2007). However, the deep freezing is not the part of common practice because of certain technological drawbacks of deep-freezing procedure and low rates of pregnancy and litter size (Vidović et al ., 2011).

The phenomenon of stress is also one of the serious problems on commercial farms. The farms that are still developing their management strategies have a mor pronounced problem with stress than farms with well-organized production system. The requirements of modern pig production today have reduced the stress to a minimum and provided maximum comfort for the animals ( welfare ). In this regard, it is important to understand the mechanisms of adaptation syndrome and stress reactions. Providing adequate living conditions for the animals positively affects their productivity that reaches the expected and desired levels. The high level of corticosteroids in the blood of animals exposed 
to stress results in the reduction in their resistance thus making them highly susceptible to various infections. Therefore, it is very important to improve the welfare of animals at farms through the development and promotion of human consciousness in view of of the respect, care and responsibility towards animals. The application of technical and technological solutions in animal production can provide maximum comfort and convenience to animals.

Technology of feeding farm animals takes an important place in the prevention of stress and is a very important factor in maintaining good health and reproductive status. Fattened sows, which carry a large number of fetuses and consume large amounts of feed in facilities with increased humidity and temperature, are more susceptible to stress and often manifest signs of respiratory distress. It is one of the reasons for the introduction of new dietary guidelines according to specific production stages and animal categories. The dietary curve for breeding sows is precisely defined for each particular stage of production in order to enable early estrus after weaning of piglets, to maximize the number of ovulated and implanted embryos, increase the number of delivering live and vital piglets, and to increase the milk yield during lactation while preserving good condition and health status of female animals. All this would prolong the life and productivity of animals and decrease the administration of drugs. Thanks to this approach, modern commercial farms are characterized by 35 or more weaned piglets per sow per year.

Pig production on commercial farms is heavily burdened by a range of diseases affecting piglets . Piglet pathology is highly dynamic within the herd as a whole, as substantial agglomeration of animals in a limited space enhances both horizontal and vertical transmission of the infection. Intensive production conditions may result in the occurrence of so called production, i.e. technological diseases caused by certain microorganisms. Variations of pathogenic organisms that commonly affect piglets are of great importance , not only in view of their resistance to drugs, but because of their potential genetic recombination affecting the clinical picture and course of the disease that may complicate the diagnosis as well as the therapeutic and prophylactic management ( Blackburn, 1995 Bojkovski et al . 1997, 2005 ). The following diseases were observed on our pig farms: neonatal colibacillosis, edema disease, necrotic enteritis, dysentery, circovirus infection, and respiratory disease complex (PRDC) .

In recent years, massive outbreaks ofrespiratory disease complex ( PRDC) were recorded on pig farms in both our country and worldwide, which is becoming a serious health problem at all technological stages of production. PRDC of pigs is a simultaneous infection of lung tissue with a number of respiratory 
pathogens and is a common term for pig pneumonia characterized by multifactorial etiology. Isolated pathogens may vary between and within production herds ( Honnold 1999, Ivetić et al . 2005 Golinar et al . 2006). The control of PRDC is difficult and complicated. The importance of respiratory disease complex is based on the interaction between multiple respiratory pathogens . Knowledge on such interactions must be taken into consideration in order to accomplish implementation of effective control measures . Respiratory disease of pigs develops as a consequence of the presence of living infective agents in the immediate surroundings of the animal or is due to a sudden drop of immunoprotective mechanism of the respiratory system ( Ivetić et al. 2005). Contrary to the control of common diffuse infectious diseases of pigs that persist in our country and are encompassed in national legislation on mandatory suppression of infectious diseases, the detection and suppression of technopathies rather represents an economic need of the producers themselves.

\section{CYTOGENETIC METHODS AS A PART OF BIOSECURITY PLANNING ON COMMERCIAL PIG FARMS}

In modern pig production, thegenetics is applied with an aim of improving productive capacity of existing breeds on commercial farms by creating breed varieties with higher genetic potential, animal growing in pure breed or cross-breeding for commercial purposes. A part of our research was focused on the investigation of karyotype changes in intensive breeding. We established that karyotype changes may occur under the influence of chemical substances, which can originate from feed, water or the environment of the investigated animals (Bojkovski et.al.2010). Our recommendation to commercial-type farms and reperoduction and artificial insermination centers implicate application of the results of cytogenetic methods that enable detection of carriers of hereditary anomalies. Implementation of these methods into the biosecurity plans on the farms will positively affect the health status of the herd and thus improve the production results.

\section{ECOLOGICAL ISSUES ON COMMERCIAL PIG FARMS}

The presence of chemical pollutants (heavy metals ) and their impact on animal health on commercial farms has been monitored for a prolonged period of time. Heavy metals, which react with organic molecules and alter their structure and function, are particularly hazardous for all living systems. Heavy metals are absorbed into the body via respiratory and digestive systems, and skin. The results of a several-year long research have pointed out the risk 
of feed contamination with heavy metals and its deposition in the body of animals, with consequences on the health and reproductive capacity of domestic animals.

The toxicity of heavy metals results in the formation of free radicals by inhibiting the activity of antioxidant enzymes and glutathione oxidation, and resulting in the creation of malonyl - dialdehyde ( MDA ) as a marker of oxidative stress. Their toxicity is derived from the tendency to form covalent links with sulfhydryl groups of biomacromolecules, or displace certain cofactors thus inhibiting the activity of particular enzymes ( Bojkovski et al . 2008a, b ,2010a).

Our recommendation for commercial farms is to apply measures for reducing the risk of toxic heavy metals, to implement multiple monitoring of the quality of raw materials and finished products as well as adequate protector of the toxic effects of these agents ( Bojkovski et al , 2010b , c )

\section{BIOSECURITY ON COMMERCIAL PIG FARMS}

Biosecurity plans are critical in the prevention of disease and unwanted situations as well as in business improvement ( Uhlehoop , 2007). The global objective of contemporary swine production in developed countries is to prevent the entry of disease in the herd, that is, maximally protect pigs from the contact with infectious agents from the environment and prevent or minimize the transfer of pathogenic organisms between certain categories of animals within the herd.. Therefore, special attention is paid to technical solutions that enable protection of pig herds from harmful external influences. Such measures include the construction of a quarantine for newly purchased animals, establishment of a separate department for the delivery of animals and special entrance for the personnel organized in line with the prescribed hygienic measures and strictly defined behavior protocol. All measures aimed at protecting the herd from infection are known as biosecurity measures and include measures of external and internal biosecurity defined in a biosecurity protocol. Outside biosecurity measures include the multi-side housing system, access control ( personnel, feed, equipment, materials, semen for artificial insemination, control of vehicles accessing the farm , control of rodents, insects and birds, entry protocols for the staff, control of animal delivery, disposal of dead animals , quarantine for newly purchased animals)and are aimed at preventing the transmission of infectious agents from the environment and other herds in the region. . Internal biosecurity pertains to procedures regulating personnel access and behavior on the farm ( shower, farm clothing, circulation of people and animals through the farm, the use of tools and equipment for the work, 
etc. ), applyingthe principle "all in-allout" protocols for cleaning, washing and disinfection as well as infection control applying a program of preventive and curative health care of animals ( Uzelac, Vasiljević, 2011). Assessment of biosecurity based on relevant indicators should be a routinemechanism for the evaluation of biosecurity on farms, indicating the direction of future operations and, possibly, their improvement (Lončarević et al, 1997, Stankovićet al., 2008). For example, based on consideration of the failures in providing biosecurity Stanković and Hristov (2009) reported the level of biosecurity on one of the investigated pig farms to be 3.96 ( very good). This result indicates the current biosecurity status of the farm, but one should always keep in mind the mutual interaction and overall activity of all biosecurity parameters (Stanković and Hristov, 2009).

The farmers bear the primary responsibility to protect their herds in terms of introduction of the disease by applying movementcontrol, by following proper procedures for housing of particular animal groups and appropriate sanitation. The personnell on the farm and visitors must be aware of their role in maintaining safe health status on the farms (Stanković and Hristov, 2009).

\section{CONCLUSION}

The aim of intensive pig farming on commercial farms is to produce a large number of weaned piglets and fatteners per sow per year. To achieve this goal, it is necessary to establish high reproductive efficiency of breeding animals . This can be achieved by adequate health care, modern technology and good organization of the production applying appropriate procedures in the technology of artificial insemination.

The main goal of modern production on commercial farms is to reduce the phenomenon of stress to the lowest possible level .

High-health status and health control applying appropriate healthcare programs along with preventive and curative measures and protocols for external and internal biosecurity are an imperative of modern pig farming.

Our recommendation for commercial farms and centers for the reproduction and artificial insemination is to apply cytogenetic methods that enable detection of carriers of hereditary anomalies.

In order to reduce the risk from the chemical pollutants, implementation of multiple monitoring of the quality of raw materials and finished products is highly required, as well as the application of adequate protective agents that minimize toxic effects of these pollutants . 


\section{ACKNOWLEDGEMENT}

This research was financially supported by the Ministry of Education, Science and Technological Development of the Republic of Serbia, project no. TR 31071

\section{REFERENCES}

1. Blackburn P.W.: Curent problems on a new approaches to pig health Chapter 7 In: The health of pigs By Jon Hill and David Sainsbury, Logman Veterinary Health Sourcies, 221-22,1995

2. Bojkovski J., Radojičić Biljana, Petrujkić B.: Savremeni aspekti u dijagnostici i terapiji uzgojnih bolesti svinja. Proceedings of workshop: "Clinica Veterinaria", Ohrid 3-7.09., 251-257. ,2005

3. Bojkovski J., Dobrić Đ., Erski-Biljić Milanka, Zakarija Dolores.: Rezistencija domaćih životinja na antibiotike i njena genetska osnova. U: I Simpozijum mutageneze, genotoksikologije, Zlatibor, 15-18 septembar. Zbornik kratkih sadržaja radova,C37,1997

4. Bojkovski J., Relić Renata, Hristov S., Stanković B., Savić B., Petrujkić T.: Contribution to knowledge of health, reproduction, biosecurity and ecological problems in intensive pig production. Bulletin UASVM, Veterinary Medicine, 67, 2, 37-39.

5. Bojkovski J., Radojičić B., Petrujkić T., Borozan S.: A contribution to insight of the most important etiological factors with influence of farm animal health in Serbia. In: Proceedings of the International Symposium on new research in biotehnology, Bucharest, Romania, Biotehnology, series F, Special volume, 101- 114, 2008a

6. Bojkovski J., Stanković B., Petrujkić T., Petrujkić B., Savić B., Đoković R., Pantić I. Turajačanin D.: Review of investigations on influence of environmental chemical contaminants on hereditary base and reproductive capacities of landras breed boars from pig farm, center for reproduction and artificial insemination and biosecurity measures in Serbia. Lucrãri stiinifice medicinã veterinarã Timisoara , 18, 2, 25-33, 2010b

7. Bojkovski J., Petrujkić T., Stanković B., Petrujkić B.: Menadžment zdravlja svinja U: Zbornik referata i kratkih sadržaja 21. Savetovanje veterinara Srbije, sa međunarodnim učešćem, Zlatibor, Zbornik kratkih sadržaja, 83, $2010 \mathrm{c}$

8. Bojkovski J., Radojičić B.,Petrujkić T., Borozan S.: Prilog poznavanju etioloških činiliaca koji utiču na zdravlje farmskih životinja. U: 20. saveto- 
vanje veterinara Republike Srbije sa međunarodnim učešćem, Zlatibor , Zbornik referata i kratkih sadržaja , 405-412, 2008

9. Bojkovski J., Savić B., Rogožarski D.: Pregled uzročnika oboljenja svinja na farmama industrijskog tipa. U: Deveti simpozijum zdravstvene zaštite selekcija i reprodujkcije svinja, Srebrno jezero, Zbornik radova, 62-75, 2011

10. Bojkovski J.: Efekti faktora sredine na kariotipske varijacije sisara, doktorska diseertcija, Univerzitet u Beogradu, Fakultet veterinaraske medicine, 1994

11. Bojkovski J., Savić B., Rogožarski D., Stojanović D., Vasiljević T., Apić I., Pavlović I.: An outline of clinical cases of disease in pigs at commercial farms. In: Proceedings of 23th International symposium " New Technologies in Conteproary Animal Production”, Novi Sad ( Serbia) 19-21 jun, 163-166.,2013a

12. Bojkovski J, Rogožarski D, Vasiljević T,Stojanović D, Savić B, Pavlović I, Relić R, Janjušević J.: Morphological changes in the kidneys of pigs caused by ochratoxin-feeding on the slaughter house (case report). Bulltein USAVM, Veterinarinary Medicine, 70, 2 195-197, 2013b

13. Golinar O.I., Valenčak Z.: Porcine respiratory disease complex(PRDC) in Slovenia.Proceedings In: The 19th Ineternational Pig Veterinary Society. Congres, Copenhagen, Denmark, 291, 2006

14. Hristov S., Stanković B., Relić Renata, Joksimović-Todorović Mirjana, Davidović, Vesna, Milojković D.: Urogenitalne infekcije priplodnih krmača. Biotechnology in animal husbandry, 22, 761 - 772.,2006

15. Hristov S., Stanković B., Relić Renata, Todorović-Joksimović Mirjana: Dobrobit i biosigurnost na farmama. Biotechnology in animal husbandry, 24 (spec.issue), 39-49., 2008

16. Honnold C.: Porcine respiratory disease complex, http//www. ces.purdue. edu/ pork health/caryhonnold.html (8 july 2008date last accessed) 1999

17. Lončarević A., Maričić Z., Tosevski J., Pavlović I.: Osnove sistematskog zdravstvenog nadzora i programiranje zdravstvene zaštite svinja u intenzivnom odgoju. U: A. Lončarević, Zdravstvena zaštita svinja u intenzivnom odgoju, Naučni institut za veterinarstvo Srbije, Beograd, 517-523,1997

18. Ivetić V., Žutić M., Savić B., Milošević B.: Kompleks respiratornih bolesti kod svinja dijagnostika i mere kontrole U: Zbornik radova i kratkih sadržaja17. Savetovanja veterinara Srbije sa medjunarodnim učešćem 7-10 septembar, 190-198, 2005

19. Petrujkić T., Bojkovski J., Petrujkić B.: Reprodukcija svinja, monografija, Naučni institut za veterinarastvo Srbije, Beograd, 2011

20. Radojičić, B., Đuričić B., Gagrčin M.: Epizootiološko-dijagnostički značaj 
kontrole reperoduktivnog i respiratornog sindroma svinja, Veterinarski glasnik, 56,1-2,231-31, 2002

21. Stančić I., Radović I., Dragin S., Erdeljan M., Apić I.: Veterinarska i zootehnološka situacija u veštačkom osemenjavanju svinja na vojvođanskim farmama, Savremena poljoprivreda, 61, 1-2, 2012

22. Stanković B., Hristov S., Petrujkić T., Relić Renata, Petrović Milica., Todorović-Joksimović Mirjana, Davidović Vesna: Polno prenosive bolesti svinja. Savremena Poljoprivreda, 56, 1-2, 99-105. 2007

23. Stanković B., Hristov S., Petrujkić T., Todorović-Joksimović Mirjana, Davidović Vesna, Bojkovski J.: Biosigurnost na farmama svinja u svakodnevnoj praksi. Biotechnology in animal husbandry, 24, 601-608, 2008

24. Stanković B., Hristov S.: Najčešći propusti u obezbeđenju biosigurnosti na farmama goveda i svinja. Zbornik naučnih radova Instituta PKB Agroekonomik, 15, 3-4,103-110, 2009

25. Tsakmakidis I.: Komparacija predviđanja fertiliteta veprova in vitro probama i klasičnih metoda evaluacije semena. U: Zbornik radova IX Simpozijuma - Zdravstvena zaštita, selekcija i reprodukcija svinja, sa međunarodnim učešćem, Srebrno jezero,2011, 116. ,2011

26. Uhlepnhoop E.: Biosecurity planning for livestock farms. Dobrobit životinja i biosigurnost na farmama.U: 1 . Međunarodna konfrencija o doborbiti i biosigurnosti na farmama u Srbiji, Zemun, 14 i 15 novembar, Poljoprivredni fakultet, Zemun, 227-237, 2007

27. Uzelac Z., Vasiljević T.: Osnove modernog svinjarstva. Petrovaradin, Futura, 2011

28. Vasiljević, T.: Tehnologija pripreme heterospermnih doza semena nerastova i ostvareni rezultati na farmama. U: Zbornik radova X Simpozijuma - Zdravstvena zaštita, selekcija i reprodukcija svinja, sa međunarodnim učešćem, Srebrno jezero 2012, 96-110, 2012

29. Vidović V., Šubara V., Višnjić V, Punoš D.: Savremeno gajenje svinja, Novi Sad, Poljoprivredni fakultet, Departman za veterinarsku medicinu., 2011

Primljeno: 15.04.2014.

Odobreno: 08.07.2014. 